\title{
Титов И.А.
}

\section{Анализ факторов и тенденций развития рынка государственных облигаций в России}

ФГОБУВО Финансовыц университет при Правительстве Российской Федераџии

(Россия, Москва)

doi: 10.18411/trnio-12-2021-60

\section{Аннотация}

В настоящее время облигационный рынок России находится в ситуации, когда дальнейшие прогнозные значения имеют большую вероятность меняться в связи с большим числом меняющихся факторов. На международном уровне условия функционирования и тенденции финансового рынка являются следствием влияния санкций и большого числа ограничений, при этом находится под риском переоценки инвесторами доходностей в случае ужесточения денежно-кредитной политики.

В статье рассмотрены понятие государственных облигаций, их значение для финансового сектора страны, определены факторы, которые оказывают влияние на формирование тенденций в части использования и востребованности государственных облигаций на современном этапе. Также в статье выявлены приоритетные причины снижения активности инвесторов, а также определены возможные направления повышения уровня доходности государственных облигаций для частных инвесторов, а значит и привлекательности данного направления на финансовом рынке.

Ключевые слова: государственные облигации, частные инвесторы, уровень доходности, инфляционные ожидания, уровень активности инвесторов, финансовый сектор.

\section{Abstract}

Currently, the Russian bond market is in a situation where further forecast values are more likely to change due to a large number of changing factors. At the international level, the operating conditions and trends of the financial market are a consequence of the impact of sanctions and a large number of restrictions, while at the same time it is at risk of revaluation of returns by investors in the event of tightening monetary policy.

The article discusses the concept of government bonds, their importance for the financial sector of the country, identifies the factors that influence the formation of trends in the use and demand for government bonds at the present stage. The article also identifies the priority reasons for the decline in investor activity, as well as identifies possible directions for increasing the level of government bond yields for private investors, and hence the attractiveness of this area in the financial market.

Keywords: government bonds, private investors, the level of profitability, inflationary expectations, the level of investor activity, the financial sector.

На современном этапе развития финансового рынка его участники в качестве одного из элементов инвестиционного портфеля выбирают государственные облигации. Данный термин подразумевает под собой использование ценных бумаг, предполагающих под собой наличие долга в определенном объеме (денежный или иной эквивалент) государства физическому или юридическому лицу на определенных условиях.

Выпуск государственных облигации на российском финансовом рынке осуществляют:

- Министерство финансов Российской Федерации;

- Министерства финансов субъектов Российской Федерации (облигации субъектов Федерации или субфедеральные облигации).

Если рассматривать значение рассматриваемого финансового инструмента для государства, то стоит отметить, что цель использования в большинстве случаев заключается в необходимости покрытия дефицита государственного бюджета. 
Другая функция государственных облигаций для финансового рынка страны заключается в том, что в сравнении с их уровнем доходности проводится назначение уровня доходности для частных размещений с низкими рисками.

Эксперты определяют государственные облигации в качестве высоко надежного инструмента, применяемого в рамках инвестиционной деятельности участников финансового рынка. Высокая надежность рассматриваемого финансового инструмента подтверждается тем, что в качестве контрагента в сделке выступает государство.

Одновременно с этим, стоит отметить, что использование государственных облигаций, как правило, сопровождается недостаточно высоким уровнем доходности по сравнению с другими финансовыми инструментами, которые используются с целью инвестирования средств, причиной является низкий уровень риска при выборе государственных облигаций.

Несмотря на то, что использование в инвестиционной деятельности государственных облигаций приносит недостаточно высокий объем доходов, данный вид вложения капитала является востребованным среди участников финансового рынка.

Данный факт подтверждают результаты исследования, которое выполнили эксперты одной из лидирующих российских брокерских платформ «Тинькофф Инвестиции». Экспертами указанной организации выявлено, что инвестирование в государственные облигации в 2020 году в качестве доли составило 7\% от объема инвестиционного портфеля участников финансового рынка. Таким образом, использование государственных облигаций является выгодным вложением средств для российских инвесторов. При этом согласно результатам исследований «Тинькофф Инвестиции» еще более востребованным с точки зрения вложения средств считается финансовый сектор, на его долю инвесторы выделяют $15 \%$ инвестиционного портфеля [1].

В настоящее время наблюдается изменение тенденций финансового рынка, как в России, так и в международном формате. Причиной этого стала пандемия COVID-19, которая может в перспективе скорректировать прогнозные значения показателей финансового рынка.

Из анализа тенденций на финансовом рынке России с точки зрения востребованности государственных облигаций среди инвесторов выявлено, что в 2019 году имели место следующие факторы, повлиявшие на его особенности:

- изменение Банком России денежно-кредитной политики, в том числе изменение ставки НДС на $2 \%$ в сторону повышения, что привело к повышению инфляционных ожиданий участников финансового рынка;

- $\quad$ повышение уровня рисков для участников сделок на финансовом рынке, в первую очередь связанных с возможным изменением регламента работы иностранных инвесторов в российскими государственными облигациями.

Действие представленных факторов привело к сокращению активности участников финансового рынка в начале 2019 года. В дальнейшем в течение 2019 года в связи с отсутствием негативного влияния указанных факторов финансовый рынок России повысил свою активность, результатом чего стала сокращение стоимости фондирования в рамках работы с облигациями, в том числе и с государственными.

В 2020 и в 2021 годах, согласно мнению экспертов, уровень доходности государственных облигаций, а также уровень устойчивости ВВП к текущему кризису влияют положительно на привлекательность работы на финансовом рынке в части выгоды для участников рынка.

Результат такой политики - сокращение оттока иностранного капитала из российского долгового рынка, а также замедление темпов сокращения стоимости государственных облигаций. 
На современном этапе изменение динамики использования государственных облигаций в качестве инструмента инвестирования средств обуславливается такими факторами, как особенности монетарной политики Банка России, стремление повысить ставки, а также совершенствование регламента относительно условий допуска розничных инвесторов к финансовым инструментам.

Если рассматривать последний из указанных факторов, то стоит отметить, что в рамках нововведений с 01.01.2021г. налог, составляющий $13 \%$ для резидентов и $30 \%$ для нерезидентов, необходимо выплачивать при использовании всех видов облигаций, как государственных, так и корпоративных. При этом именно брокер будет являться ответственным по расчету и сбору нового налога.

Если рассматривать статистические данные, то необходимо отметить, что доходность российских государственных облигаций повышается в настоящее время: при сравнении значений данного показателя в 2020 и в 2021 году выявлено, что в 2020 году уровень доходности составлял 4,14\%, а в 2021 году он равен 6,92\% [2].

Анализ динамики объемов выпуска государственных облигаций на современном этапе показал, что российское правительство стремится повысить их востребованность, на данный факт указывает повышение объемов размещений на аукционах ОФЗ до 143 млрд рублей в феврале 2021 года.

Следующая тенденция современного финансового рынка с точки зрения востребованности государственных облигаций и структуры участников - это сокращение доли нерезидентов на аукционах ОФЗ до 20\%. Одновременно с этим, объемы приобретаемых государственных облигаций возросли до 29 млрд. руб. [3].

Таким образом, представленные данные позволяют сделать вывод о сокращении объемов приобретаемых государственных облигаций на внутреннем рынке, при этом имеет место формирование стабильной позиции на валютных свопах.

Другие факторы, которые обеспечивают повышение доходности государственных облигаций в России на современном этапе - это повышение инфляционных ожиданий ввиду изменений на финансовом рынке США, оказывающий влияние на мировой финансовый рынок в целом, а также повышение рисков инвестирования из-за периодических санкционных мероприятий относительно экономики России со стороны мировых лидеров.

Таким образом, из исследования факторов и тенденций функционирования финансового рынка в части использования государственных облигаций, следует, что на динамику и структуру финансового рынка оказывают влияние не только политика государственных органов России в части регламента работы, но и отношения страны на международном уровне, в том числе и вводимые санкции против России, что в дальнейшем повышает инфляционные ожидания участников финансового рынка, тем самым снижает их активность.

Одновременно с этим, большинство экспертов отмечают, что в случае повышения уровня инфляции на достаточно продолжительный срок в перспективе, необходимо повысить срок погашения предлагаемых инвесторам ценных бумаг, в том числе государственных облигаций, что позволит им сохранить уровень доходности на более длительный период.

1. Investing.com. Россия - Государственные Облигации. Режим ввода: [https://ru.investing.com/rates-bonds/russiagovernment-bonds?maturity_from=10\&maturity_to=130] (Дата обращения: 20.09.2021)

2. Банк России. Обзор рисков финансовых рынков. Информационно-аналитический материал. 2021. Режим ввода: [http://www.cbr.ru/Collection/Collection/File/32076/ORFR_2021-02.pdf] (Дата обращения: 20.09.2021)

3. Официальный сайт «Тинькофф». Тинькофф Инвестиции составили «Портрет современного розничного инвестора». 14.02.2020г. Режим ввода: [https://www.tinkoff.ru/about/news/14022020-tinkoff-investmentsresearch-retail-investor-portrait/] (Дата обращения: 20.09.2021) 